10.2478/cer-2018-0009

\title{
On a Production Function of European Countries: An Empirical Study
}

\begin{abstract}
The aim of this paper is to examine the goodness-of-fit of several aggregated production functions including the Cobb-Douglas function, the Mankiw, Romer and Weil model, or Mincer's specification for a set of 30 European countries during the period 2006-2015. The dependent variable was economic output measured in real GDP, while the set of independent variables included labour, physical capital, human capital, labour productivity or technology level. The main finding of the paper is that all the above-mentioned aggregate production functions fitted the data exceptionally well, with the adjusted coefficients of determination above 0.95. Also, it was found that the inclusion of other macroeconomic variables, such as labour productivity, human capital or technology level to the two-factor Cobb-Douglas function did not result in a significantly better goodness-of-fit.
\end{abstract}

Keywords: cross-sectional study, production function, European countries

JEL: E01, E23, R12

* Ph.D., Silesian University in Opava, School of Business Administration in Karviná, Department of Informatics and Mathematics, Opava, Czech Republic, e-mail: mazurek@opf.slu.cz 


\section{Introduction}

To describe the output of an economy, several growth models (functions or specifications) were proposed in the literature. The oldest one is a two-factor (capital and labour) Cobb-Douglas production function (Cobb and Douglas 1928). Another well-known production functions include the constant-elasticity-to-substitution (CES) production function introduced by Solow (1957), the Mankiw, Romer and Weil (MRW) model, see Mankiw, Romer and Weil (1992), or Mincer's specification (Mincer 1974).

Although the above-mentioned production functions are often used in macroeconomics, especially in growth studies (see for example Islam (1995)), papers focusing on the empirical evidence of their validity for a cross-section of countries are rather rare. Duffy and Papageorgiou (2000) used aggregate data on a panel of 82 countries over 28 years. Their results suggested that the Cobb-Douglas (CD) specification was not valid, with the data showing more support for a more general CES specification. Room (2001) provided a comparison of aggregate Cobb-Douglas production functions of Central and East European countries in the late 1990s to examine their potential output. Ferreira et al. (2003) examined aggregate MRW production functions and its mincerian modification for a panel of 95 countries over the period 1960-1985. Their results showed that the mincerian model was more appropriate than MRW. Dissanayake and Sim (2010) used the CES function with two factors, capital and labor, for a panel of 82 countries over 1960-1987. They found substantial heterogeneity in the production function across countries. Poorer countries had lower capital shares, higher elasticity of substitution and non-decreasing returns to scale, and richer countries vice versa.

Except for the aforementioned Ferreira at al. (2003) paper, the goodness-of-fit of different aggregate production functions with respect to empirical data has not been examined so far.

Therefore, the aim of this study is to examine the goodness-of-fit of several aggregated production functions, including CD function, the MRW model and Mincer's specification, for a set of 30 (maximum available) European countries during the period 2006-2015. Because the last decade was rather turbulent in terms of economics, covering the Great Recession and a rather strong growth prior to the Recession, the averaged data from 2006-2015 were used for the estimations rather than panel data.

Furthermore, a new term (proxy) expressing the technology level of a country was added into the Cobb-Douglas production function to examine whether it can improve its goodness-of-fit. This technology term was extracted from World Bank databases as a percentage of high-tech exports to all exports for a given country.

The paper is organized as follows: in section 2, production functions and models are described, section 3 provides the data and method of the study, and finally, section 4 provides the results. Conclusions close the article. 


\section{Aggregate production functions and models}

Almost a century ago, economists C. W. Cobb and P. H. Douglas (Cobb and Douglas, 1928) introduced a two-factor production function:

$$
Y=A K^{\alpha} L^{\beta},
$$

where $Y$ denotes total production, $K$ is physical capital, $L$ is labour and $A$ is the total factor productivity, and $\alpha$ and $\beta$ are output elasticities of capital and labour respectively. If $\alpha+\beta=1$, then the function (1) displays constant returns to scale.

Later, modifications and extensions of the CD function (1) were introduced. To the two factors ( $K$ and $L$ ), other inputs, such as labour productivity, human capital or level of technology, were added. In this paper, the following aggregate production functions (2-7) are going to be empirically examined:

$$
Y=A K^{\alpha} L^{\beta} P^{\gamma},
$$

where $P$ is labour productivity.

$$
Y=A K^{\alpha}(P L)^{\beta},
$$

where the product of $P$ and $L$ act as one factor, and:

$$
Y=A K^{\alpha} L^{\beta} P^{\gamma} T^{\delta},
$$

where $T$ is the technology term (the level of technology).

Mankiw, Romer and Weil (1992) proposed a model of the following form:

$$
Y=A K^{\alpha} H^{\varphi}\left(L e^{g}\right)^{\beta},
$$

where $H$ is the level of human resources, $A$ productivity and $g$ exogenous technological progress considered the same across countries.

Mincer (1974) provided slightly different specification:

$$
Y=A K^{\alpha}[\exp (H \varphi) L \exp (g)]^{\beta}
$$

From an econometric point of view, relations (5) and (6) differ only in $H$, which enters (5) in logs while $H$ enters (6) in levels, after logarithmic transformation. 


\section{Data and method}

For this study, European countries were selected. The main reasons for this selection were data availability and reliability from Eurostat's databases. Furthermore, European developed economies constitute a relatively homogenous sample without outliers, which might result in better (stronger) statistical findings.

Out of approximately 40 countries covered by Eurostat's databases, only 30 countries fulfilled the data requirements (their data were complete). For the linear regression, the following data were gathered from the countries:

- Output $(Y)$, given as the real gross domestic product (GDP) at market prices from Eurostat (2016).

- Physical capital $(K)$, given as gross capital formation (produced non-financial assets) in millions of euros (current prices) from Eurostat (2016).

- Human capital $(H)$, given as the mean years of schooling of adults from the Human Development Report Office (2013).

- Labour $(L)$, given as the average number of usual weekly hours of work in a main job, Eurostat (2016).

- Labour productivity $(P)$, given as the labour productivity per hour worked from Eurostat (2016).

- Technology level $(T)$, given as the high technology exports (\% of manufactured exports) from World Bank (2016).

The annual data of all six aforementioned variables and all 30 European countries were averaged over the period 2006-2015. In the case of human capital, the last available data (the mean schooling years of adults) ended in 2013, so for this variable, the average from 2006 to 2013 was used for estimations. As the number of schooling years is a variable with large inertia, the end of data in 2013 should not be considered a problem. To describe (supposedly) different technology level of countries, the technology level (T) variable was included in the study.

The averaged data, which are shown in Appendix A, formed the input for the log-transformed (linearized) aggregate production functions (1-6):

$$
\begin{gathered}
\ln Y_{i}=\ln A_{i}+\alpha \ln K_{i}+\beta \ln L_{i}+\varepsilon_{i}, \\
\ln Y_{i}=\ln A_{i}+\alpha \ln K_{i}+\beta \ln L_{i}+\gamma \ln P_{i}+\varepsilon_{i}, \\
\ln Y_{i}=\ln A_{i}+\alpha \ln K_{i}+\beta \ln L_{i}+\beta \ln P_{i}+\varepsilon_{i}, \\
\ln Y_{i}=\ln A_{i}+\alpha \ln K_{i}+\beta \ln L_{i}+\gamma \ln P_{i}+\delta \ln T_{i}+\varepsilon_{i},
\end{gathered}
$$




$$
\begin{gathered}
\ln Y_{i}=\ln A_{i}+\alpha \ln K_{i}+\varphi \ln H_{i}+\beta \ln L_{i}+\beta g+\varepsilon_{i}, \\
\ln Y_{i}=\ln A_{i}+\alpha \ln K_{i}+\varphi \beta H_{i}+\beta \ln L_{i}+\beta g+\varepsilon_{i} .
\end{gathered}
$$

Before the linear regression was performed via Gretl, the correlation among variables was examined to assess possible linear dependence among variables. From the correlation matrix in Table 1, it can be seen that selected variables were rather uncorrelated with the exception of the pair $(Y, K)$, which is somewhat comprehensible.

As for multicollinearity, the largest VIF (variance inflation factor) was detected for the $\ln L$ variable, where $\operatorname{VIF}(\ln L)=1.70$. The rule of thumb (see, e.g., O'Brien (2007)) states that the problem of multicollinearity arises when VIF exceeds the value of 10 . Therefore, the problem of potential multicollinearity of the data of interest could be dismissed.

In the second step, assumptions regarding the use of the ordinary least squares (OLS) method were checked, with the result that the OLS can be used for all models if the heteroscedasticity present in the data is corrected. Therefore, the OLS with corrected heteroscedasticity, which is a built-in method in Gretl, was performed.

\begin{tabular}{|c|c|c|c|c|c|c|}
\hline$Y$ & $K$ & $L$ & $P$ & $\boldsymbol{H}$ & $T$ & \\
\hline 1 & $\begin{array}{c}0.8962 \\
(0.979) \\
\end{array}$ & $\begin{array}{c}-0.3204 \\
(-0.451) \\
\end{array}$ & $\begin{array}{r}-0.1130 \\
(-0.237) \\
\end{array}$ & $\begin{array}{c}0.1534 \\
(0.116)\end{array}$ & $\begin{array}{r}0.0746 \\
(-0.363) \\
\end{array}$ & $\boldsymbol{Y}$ \\
\hline & 1 & $\begin{array}{l}-0.3020 \\
(-0.440) \\
\end{array}$ & $\begin{array}{r}-0.0577 \\
(-0.197) \\
\end{array}$ & $\begin{array}{c}0.0680 \\
(0.111) \\
\end{array}$ & $\begin{array}{r}0.0153 \\
(-0.090) \\
\end{array}$ & $\boldsymbol{K}$ \\
\hline & & 1 & $\begin{array}{r}0.0655 \\
(0.063)\end{array}$ & $\begin{array}{c}-0.3273 \\
(-0.314)\end{array}$ & $\begin{array}{c}-0.2906 \\
(-0.396)\end{array}$ & $L$ \\
\hline & & & 1 & $\begin{array}{c}0.1915 \\
(0.191)\end{array}$ & $\begin{array}{r}-0.0337 \\
(-0.084) \\
\end{array}$ & $P$ \\
\hline & & & & 1 & $\begin{array}{c}0.0438 \\
(0.234)\end{array}$ & $\boldsymbol{H}$ \\
\hline & & & & & 1 & $T$ \\
\hline
\end{tabular}

Table 1. Correlation matrix of all variables and their logs (in brackets)

Source: own calculations.

\section{Results and discussion}

After linearization of models (1-6), the linear regression was performed. For the estimation method, the ordinary least squares (OLS) with corrected heteroscedasticity was performed in Gretl. 
The results are summed up in Table 2. Figures 1 and 2 provide the relationship between the logarithm of GDP and the logarithms of labour and human capital respectively for all 30 examined countries.

As can be seen from Table 2, the two-factor CD function fits the data very well, with the adjusted coefficient of determination as high as 0.96 . The inclusion of labour productivity $P$ resulted in only a very slim increase in adjusted $R^{2}$, whereas the inclusion of $P$ and $T$ simultaneously yielded the model with the adjusted $R^{2}=0.99$. The MRW model and Mincer's model proved to be equally good, with the adjusted $R^{2}=0.96$.

As for the value of the coefficients, the logarithm of capital $K$ was found very close to 1 for all six models. Interestingly, all six models provided consistently negative values for the logarithm of labour. This result is difficult to explain, as according to the macroeconomic theory, with growing labour, an input (GDP) should also increase. In other words, an exponent of labour in the CD function (or in another production function) should be positive. However, this is not the case in the presented study. Figure 1, which shows a dependence of the logarithm of GDP on the logarithm of labour, clearly indicates a negative relationship between the two variables present in the data, the conclusion only confirmed by linear regressions.

One possible explanation is that the poorer countries (countries with the lower GDP and physical capital) substituted the missing capital with labour, but they still lag behind the richer countries. On the other hand, the use of human capital instead of labour seems to be empirically more reasonable, see Figure 2 . The higher the human capital, the larger the output, as might be expected, though this relationship is rather weak.

Table 2. Models and their estimations - summary of results

\begin{tabular}{|c|c|c|c|}
\hline Model & $\begin{array}{c}\text { Estimation } \\
\text { method }\end{array}$ & $\begin{array}{c}\text { Model output } \\
\text { Coefficients of variables }\end{array}$ & $\begin{array}{c}\text { Number of observations } \\
\text { Coefficient of determination }\end{array}$ \\
\hline (7) & $\begin{array}{l}\text { OLS with corrected } \\
\text { heteroscedasticity }\end{array}$ & $\begin{array}{l}\text { const.: } 18.08(3.77)^{* * *} \\
\operatorname{lnK}: 1.006(0.039)^{* * *} \\
\operatorname{lnL}:-0.765(0.978)\end{array}$ & $\begin{array}{c}n=30 \\
R^{2} \text { (adj.) }=0.967\end{array}$ \\
\hline (8) & $\begin{array}{l}\text { OLS with corrected } \\
\text { heteroscedasticity }\end{array}$ & $\begin{array}{l}\text { const.: } 37.24(9.33)^{* * *} \\
\operatorname{lnK}: 0.996(0.031)^{* * *} \\
\operatorname{lnL}:-0.853(0.778) \\
\ln \mathrm{P}:-4.063(2.039)^{*}\end{array}$ & $\begin{array}{c}n=30 \\
R^{2} \text { (adj.) }=0.979\end{array}$ \\
\hline (9) & $\begin{array}{l}\text { OLS with corrected } \\
\text { heteroscedasticity }\end{array}$ & $\begin{array}{l}\text { const.: } 20.53(4.15)^{* * *} \\
\operatorname{lnK}: 0.991(0.033)^{* * *} \\
\ln (\mathrm{PL}):-1.390(1.086)\end{array}$ & $\begin{array}{c}n=30 \\
R^{2} \text { (adj.) }=0.978\end{array}$ \\
\hline (10) & $\begin{array}{l}\text { OLS with corrected } \\
\text { heteroscedasticity }\end{array}$ & $\begin{array}{l}\text { const.: } 30.01(8.25)^{* * *} \\
\operatorname{lnK}: 1.006(0.014)^{* * *} \\
\operatorname{lnL}:-0.158(0.443) \\
\operatorname{lnP}:-3.111(1.764)^{*} \\
\operatorname{lnT}: 0.087(0.039)^{* *}\end{array}$ & $\begin{array}{c}n=30 \\
R^{2} \text { (adj.) }=0.998\end{array}$ \\
\hline
\end{tabular}




\begin{tabular}{|c|c|c|c|}
\hline Model & $\begin{array}{c}\text { Estimation } \\
\text { method }\end{array}$ & $\begin{array}{c}\text { Model output } \\
\text { Coefficients of variables }\end{array}$ & $\begin{array}{c}\text { Number of observations } \\
\text { Coefficient of determination }\end{array}$ \\
\hline (11) & $\begin{array}{l}\text { OLS with corrected } \\
\text { heteroscedasticity }\end{array}$ & $\begin{array}{l}\text { Const: } 18.83(4.96)^{* * *} \\
\operatorname{lnK}: 1.009(0.04)^{* * *} \\
\operatorname{lnL}:-0.977(1.10) \\
\ln \mathrm{H}:-0.007(0.66)\end{array}$ & $\begin{array}{c}n=30 \\
R^{2} \text { (adj.) }=0.961\end{array}$ \\
\hline (12) & $\begin{array}{l}\text { OLS with corrected } \\
\text { heteroscedasticity }\end{array}$ & $\begin{array}{l}\text { Const: } 17.94(4.46)^{* * *} \\
\operatorname{lnK}: 1.012(0.042)^{* * * *} \\
\operatorname{lnL}:-0.781(1.09) \\
\mathrm{H}: 0.012(0.06)\end{array}$ & $\begin{array}{c}n=30 \\
R^{2} \text { (adj.) }=0.962\end{array}$ \\
\hline
\end{tabular}

Note: * statistically significant at 0.10 level, ** at 0.05 level and $* * *$ at 0.01 level.

Source: own calculations.

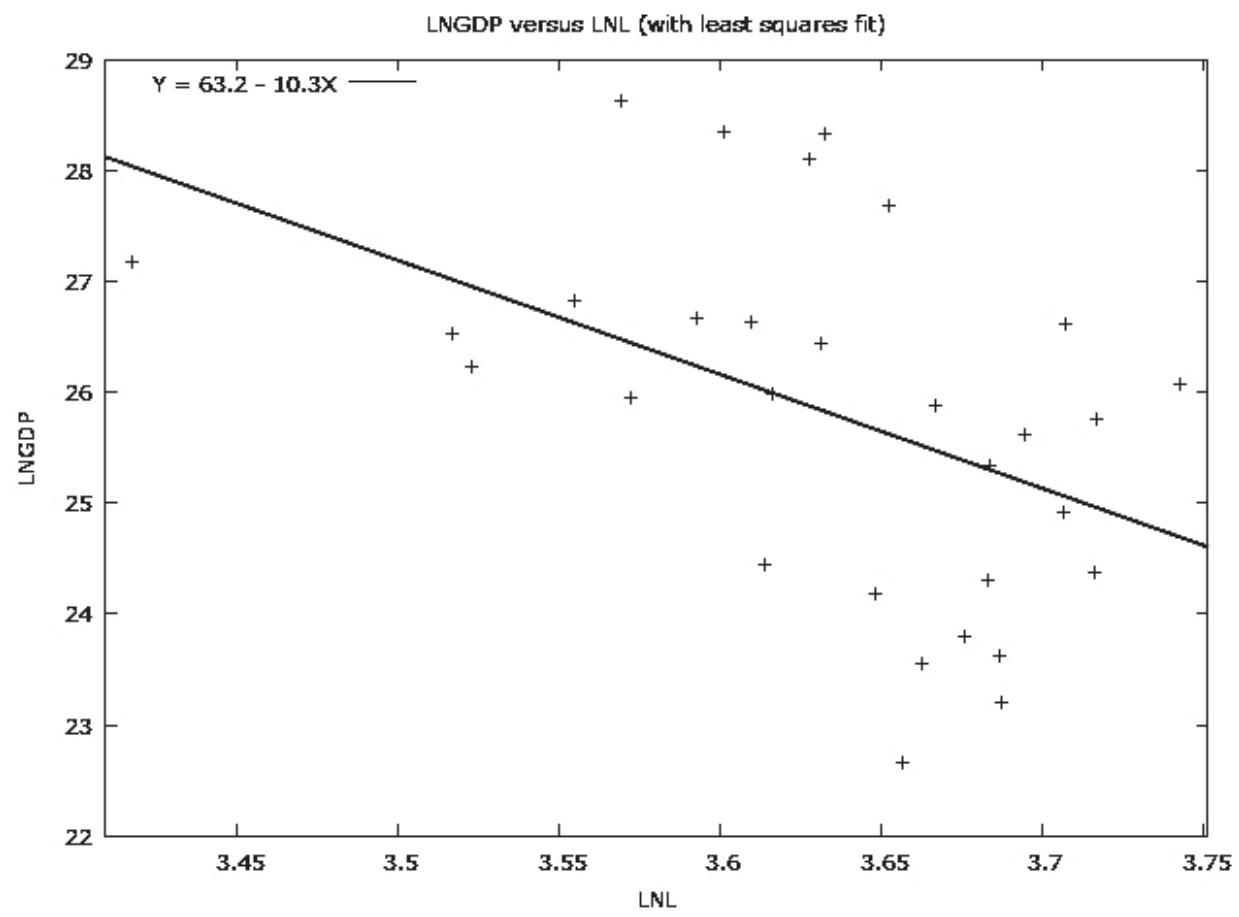

Figure 1. Logarithm of labour vs. logarithm of GDP for all 30 countries

Source: Eurostat (2016). 


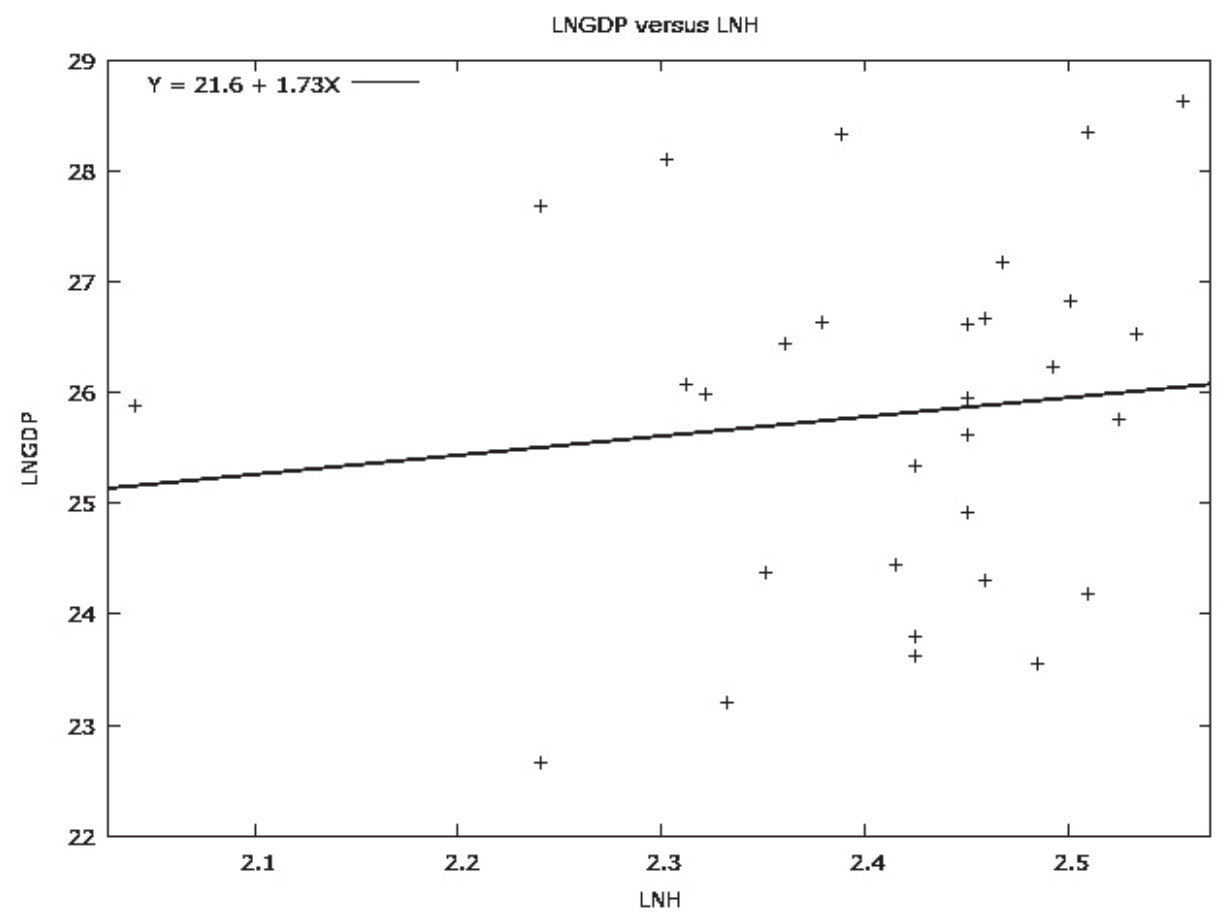

Figure 2. Logarithm of human capital vs. logarithm of GDP for all 30 countries Source: Eurostat (2016), HDRO (2013).

\section{Conclusions}

The aim of the paper was to examine the goodness-of-fit of several aggregate production functions for a set of 30 European countries in the 2006-2015 period. The main finding is that Cobb-Douglas production function, Mankiw-Romer-Weil model and Mincer's specification fitted the (averaged) data exceptionally well with the adjusted coefficient of determination exceeding 0.95 . Therefore, the question as to which production function fits the empirical data better can be answered so that all three production functions fitted the data equally well.

While this study examined European countries, which are rather homogenous from an economic point of view, further research may focus on a broader set of countries, or on developing countries, where more diversity might be expected. 


\section{Acknowledgments}

This paper was supported by the Ministry of Education, Youth and Sports, Czech Republic, within the Institutional Support for the Long-term Development of a Research Organization in 2018.

\section{References}

Cobb, C. W., Douglas, P.H. (1928), A Theory of Production, ‘American Economic Review', 18.

Dissanayake, J., Sim, N. (2010), Cross Country Empirical Investigation of the Aggregate Production Function Using Panel Quantile Regression. [In]: Proceedings of the 39th Australian Conference of Economists (ACE 10).

Duffy, J., Papageorgiou, C. (2000), A Cross-Country Empirical Investigation of the Aggregate Production Function Specification, 'Journal of Economic Growth', 5.

Eurostat. (2016), available from: http://ec.europa.eu/eurostat/data/database.

Ferreira, F. C., Issler, J.V., Pessoa, S. (2003), Testing Production Functions used in Empirical Growth Studies, 'Ensaios Economicos', 507.

Human Development Report Office. (2013), available from: http:/hdr.undp.org/en/2013-report.

Islam, N. (1995), Growth Empirics: A Panel Data Approach, 'Quarterly Journal of Economics', 110 (4).

Mankiw, N. G., Romer, D., Weil, D. N. (1992), A contribution to the Empirics of Economic Growth, 'Quarterly Journal of Economics', 107.

Mincer, J. (1974), Schooling, Experience and Earning, 'NBER', 1-4.

O'Brien, R. M. (2007), A Caution Regarding Rules of Thumb for Variance Inflation Factors. 'Quality and Quantity', 41(5).

Room, M. (2001), Potential Output Estimates for Central and East European Countries Using Production Function Method, 'Working papers of Eesti Pank', 2.

Solow, R. M. (1957), Technical Change and the Aggregate Production Function, 'Review of Economics and Statistics', 39.

WorldBank. (2016), available from: http://data.worldbank.org/. 


\section{APPENDIX A}

The data used for linear regression models.

\begin{tabular}{|l|c|c|c|c|c|c|}
\hline \multicolumn{1}{|c|}{ Country } & $\mathbf{Y}$ & $\mathbf{K}$ & $\mathbf{L}$ & $\mathbf{P}$ & $\mathbf{T}$ & $\mathbf{H}$ \\
\hline Belgium & $3.7047 \mathrm{E}+11$ & 86757.45 & 36.95 & 99.47 & 10.35 & 10.8 \\
\hline Bulgaria & 38795918812 & 9854.42 & 41.11 & 101.25 & 7.24 & 10.5 \\
\hline Czech Republic & $1.52857 \mathrm{E}+11$ & 42512.7 & 41.13 & 101.31 & 14.8 & 12.5 \\
\hline Denmark & $2.4654 \mathrm{E}+11$ & 51447.95 & 33.9 & 100.57 & 15.51 & 12.1 \\
\hline Germany & $2.69454 \mathrm{E}+12$ & 529356.2 & 35.49 & 101.32 & 15.46 & 12.9 \\
\hline Estonia & 16857727677 & 4790.45 & 38.98 & 99.39 & 9.63 & 12 \\
\hline Ireland & $1.87523 \mathrm{E}+11$ & 42292.04 & 35.6 & 102.3 & 24.77 & 11.6 \\
\hline Greece & $2.08824 \mathrm{E}+11$ & 37654.06 & 42.23 & 98.5 & 9.59 & 10.1 \\
\hline Spain & $1.05884 \mathrm{E}+12$ & 255523.9 & 38.57 & 100.26 & 6.47 & 9.4 \\
\hline France & $2.02127 \mathrm{E}+12$ & 462227.2 & 37.81 & 101.1 & 23.54 & 10.9 \\
\hline Italy & $1.59499 \mathrm{E}+12$ & 313451.8 & 37.63 & 100.33 & 7.1 & 10 \\
\hline Cyprus & 18236866340 & 3670.68 & 39.93 & 101.53 & 20.9 & 11.3 \\
\hline Latvia & 21589778394 & 5935.78 & 39.48 & 103.39 & 9.73 & 11.3 \\
\hline Lithuania & 31838314444 & 6753.16 & 38.41 & 103.56 & 10.36 & 12.3 \\
\hline Luxembourg & 41087393312 & 8198.5 & 37.12 & 100.24 & 8.02 & 11.2 \\
\hline Hungary & $1.0099 \mathrm{E}+11$ & 22344.4 & 39.8 & 97 & 20.48 & 11.3 \\
\hline Malta & 6888212793 & 1397.64 & 38.73 & 101.92 & 45.37 & 9.4 \\
\hline Netherlands & $6.34825 \mathrm{E}+11$ & 132202.2 & 30.5 & 100.61 & 21.55 & 11.8 \\
\hline Austria & $3.02951 \mathrm{E}+11$ & 70760.3 & 37.76 & 100.52 & 12.5 & 10.6 \\
\hline Poland & $3.6135 \mathrm{E}+11$ & 78490.28 & 40.75 & 100.33 & 6.2 & 11.6 \\
\hline Portugal & $1.7432 \mathrm{E}+11$ & 33404.21 & 39.13 & 99.86 & 5.36 & 7.7 \\
\hline Romania & $1.34364 \mathrm{E}+11$ & 36721.72 & 40.23 & 106.42 & 7.13 & 11.6 \\
\hline Slovenia & 36093498390 & 8696.94 & 39.77 & 101.84 & 5.9 & 11.7 \\
\hline Slovakia & 66831517515 & 16096.02 & 40.73 & 101.01 & 7.69 & 11.6 \\
\hline Finland & $1.93093 \mathrm{E}+11$ & 43868.4 & 37.21 & 100.44 & 12.4 & 10.2 \\
\hline Sweden & $3.84341 \mathrm{E}+11$ & 89999.85 & 36.34 & 100.77 & 13.44 & 11.7 \\
\hline United Kingdom & $2.06186 \mathrm{E}+12$ & 84526.96 & 36.64 & 99.74 & 21.85 & 12.3 \\
\hline Iceland & 11993922150 & 2545.81 & 39.95 & 100.8 & 28.82 & 10.3 \\
\hline Norway & $3.3309 \mathrm{E}+11$ & 79345.59 & 33.69 & 100.88 & 17.64 & 12.6 \\
\hline Switzerland & $4.50873 \mathrm{E}+11$ & 97449.01 & 34.98 & 99.89 & 25.32 & 12.2 \\
\hline & & & & & & \\
\hline
\end{tabular}

Source: Eurostat (2016), Worldbank (2016), HDRO (2013). 


\section{Streszczenie}

\section{O FUNKCJI PRODUKCJI W KRAJACH EUROPEJSKICH: STUDIUM EMPIRYCZNE}

Celem niniejszego artykułu jest zbadanie zgodności dopasowania kilku zagregowanych funkcji produkcji, w tym funkcji Cobba-Douglasa, modelu Mankiwa, Romera i Weila czy specyfikacji Mincera dla zestawu 30 krajów europejskich w okresie 2006-2015. Zmienna zależna byt wynik gospodarczy wyrażony realnym PKB, natomiast zbiór zmiennych niezależnych obejmowat siłę robocza, kapitał fizyczny, kapitał ludzki, wydajność pracy czy poziom technologii. Głównym odkryciem artykułu jest stwierdzenie, że wszystkie wyżej wymienione zagregowane funkcje produkcji byty wyjątkowo dobrze dopasowane do danych empirycznych, przy skorygowanych współczynnikach determinacji powyżej 0,95. Stwierdzono również, że włączenie innych zmiennych makroekonomicznych, takich jak wydajność pracy, kapitat ludzki lub poziom technologii do dwuskładnikowej funkcji Cobba-Douglasa, nie spowodowało znaczacej poprawy zgodności dopasowania.

Stowa kluczowe: badanie przekrojowe, funkcja produkcji, kraje europejskie 